\title{
A Qualitative Comparison on Guidelines for Construction Workers Accommodation and Facility
}

\author{
Norasyikin Khamis ${ }^{1, *}$, Azeanita Suratkon ${ }^{1}$, Hairuddin Mohammad ${ }^{2}$, and Siti Khalijah \\ Yaman $^{1}$ \\ ${ }^{1}$ Faculty of Civil and Environmental Engineering, Universiti Tun Hussein Onn Malaysia, Johor, \\ Malaysia \\ ${ }^{2}$ Faculty of Architecture, Planning and Survey, University of MARA Technology, Shah Alam, \\ Malaysia
}

\begin{abstract}
Construction industry in Malaysia covers almost 1.3 million workers. Thus, realizing the importance of human-centred trait, a longterm plan that is led by the Construction Industry Development Board Malaysia (CIDB) has been designed to improve accommodation and facilities of workers at construction site. In conjunction to that, the Institute for Industrial Research and Standards Malaysia (SIRIM) has developed Malaysia Standard (MS 2593:2015) as the guideline for improvement of accommodation and facilities for workers which is able to contribute to the achievement of the target in the Construction Industry Transformation Programme (CITP). However, a phenomenon that is centred on the level of itscorroboration compared with other similar guidelines has been voiced by some practitioners of construction, especially when the guideline are likely to be the basis of a new related act. Therefore, based on MS 2593:2015, this introductory research is conducted to qualitatively analyse the corroborative level of the guideline compared to its counterpart guidelines. By using a comprehensive document analysis method which anchored to frequency approach and assisted by NVivo v. 8 software, the report found out that the Malaysia-based guideline is on par to the restwith some introduction of new variables (especially towards leisure and social aspects). Thus, further research on gauging industry's willingness and existing compliance rates is deemed appropriate in order to inculcate positive impacts towards the objectives of MS 2593:2015, and subsequently contributes to the formation of the forthcoming corresponding act.
\end{abstract}

\section{Introduction}

According to Dato' Sri Haji Fadillah Bin Haji Yusof, Minister of Work, the industry has contributed to double-digit growth and maintaining its momentum until recently as new projects and interests were steadily in place [1]. Apart from becoming an important catalyst

*Corresponding author: azeanita@uthm.edu.my 
for the nation, its positive spill over effects have nurtured an influx of foreign worker forces in supporting the needs of construction industry [2]. Up to this moment, there are almost 2.1 million workers (minus management staff) pinning on the industry, which large portion of them come from foreign countries [3]. Following the circumstance, providing adequate accommodations and facilities for the workers is paramount, especially towards the responsible parties[4].

In Workers Act 446, those who are responsible for the employees must provide comfortable and adequate accommodations and facilities even if they are foreign workers [5]. Additionally, another similar tone was observed from the Board of Inquiry Act 1990, where responsible parties must ensure that the accommodation of workers has to meet the minimum requirements in accordance with set of standards that is currently available [5]. Lending support to the previous acts, according to a statement made by the Director of Strategic Communications and Public Relations of MRT Corp; Mahmood Abdul Razak, providing systematic and comfortable accommodations and facilities of foreign workers is able to overcome the social problems that currently exist in the local community, which particularly related to problem with drugs within foreign construction workers [6]. Furthermore, issue of accommodation and facilities of construction workers had become a highlight in the recent Construction Industry Transformation Programme (CITP), where improvisation under the purview of CIDB is repeatedly mentioned in order to meet demands of future economy [1].

Thus, noting on the importance of having proper guideline, an effort by the Department of Public Works (JKR) are visualised through their Standard Specifications for Building Works. The exact document describes briefly the need for workers' necessities which can be found in Section A (Preliminary and General Requirements), within a specific Article 28 (Contractor's Temporary Accommodation and Facilities for Workmen Living on Site [7]. Inside, it lists thirteen needs that basically determine the type of material used for workers' accommodation, size of the building and space allocation, amenities and basic facilities to be provided, and person's responsible for keeping and maintaining a list of employees and others shared accommodation sites [7]. Parallel to JKR's guideline, recent publication by the Institute for Industrial Research and Standards Malaysia (SIRIM) on Malaysia Standard of Temporary Construction Site Workers' Amenities and Accommodation (MS 2593:2015) has further strengthened existing measures on national scale. However, since this is a newly published standard, scarcity of in-depth post-study pertaining the interoperability of the standard is very much profound.

These issues do not only lie on the comprehensiveness of the standard per se, but how the standard will behave towards its actual implementation in the construction industry, especially by the imposing organisation (i.e. contractors). Along with future moves by the authorities that intended to gazette an act out of the MS 2593:2015 [4], collective findings are indeed needed to encapsulate their corroborative level, preparedness level, and current tangible milestones. Significant gaps might emanate across the findings which subsequently lend support for any betterments, together with profound constructive spill over effects towards holistic strategies to implement the particular standard. Therefore, in this precise paper, the authors were intrigued to answer the question of 'what?' regarding its corroborative level, which generally attached to the particular standard's fared among its counterparts.

\section{Construction site}

According to Business \& Group (2012), construction sites can be classified asa project's place where there are many dangerous moving machineries and equipment, and contain construction works such as excavation, piling, etc. In other words, it is a place where 
physical construction works are commenced and utilisation of 4M's (i.e. manpower, machines, materials, and money) is abundance, along with properly placement of hoarding to differentiate its boundary. Therefore, apart from being a workplace for incoming generation [8], compliances with safety requirements are essential in construction site, including the application of safety helmet, safety shoes, and others, where priority is given to safety and health of workers[9].

There are generally three (3) types of work involved in a building concept which are minor construction, major construction, and off-site construction [10]. Minor construction is normally at fixed locations having less than ten employees at a time, with construction period of less than two years. Typically referred as small scale construction, these clusters include newly build building or renovation exercise. On the other hand, major construction is classified under fixed location where there are more than 10 employees working for two consecutive years. Some of the examples are an engineering construction of dam and construction of new housing scheme. Meanwhile, off-site construction is normally categorised as automation-led construction majorly done in large factories, where often associated with prefabricated building components.

\section{Construction worker}

By and large, construction worker is defined as fully utilisable human resources [11]. According to the Employment Act 1955, Section 2 (1), domestic worker is a worker who is the citizen of this country, and employed with salary as a reward for their contract of service [12]. Indirectly, those definitions are no different to majority of foreign construction workers (e.g. Indonesians, Bangladeshis, Burmese, Vietnamese, etc.) except for their citizenship which in a way differentiate them to indigenous construction workers. Their presence in this country is particularly due to the need of industry in coping with rising number of projects, and to a certain extent, plugging serious lacking of Malaysians workers faced by the construction industry [13]. Although prioritisation and recruitment efforts were given to local workers before any initiative of procuring foreign workers were made[14], issue on shortages of worker is still persisted, hence influxes of them were inevitable [15].Apart from that, workers in the Malaysia's construction industry can be categorised into three (3) broad types, namely; skilled worker, semi-skilled worker, and unskilled worker [14]. However, only semi-skilled and unskilled worker are classed as foreign workers [16].

Skilled workers are defined to be efficient, with exceptional skills, and able to use newer equipment to carry out entrusted works [17]. Basically, five (5) to ten (10) years is required for a person to achieve the status. Meanwhile, semi-skilled workers are defined as workers who have skills in one or more branches of construction trades, but yet to reach similar skills 'level that of skilled worker[17]. Typically, they become assistants to skilled worker, nonetheless there are times when they can produce quality workmanship on par with skilled worker especially when their accumulated years of service are higher. Working based on past experiences and coupled with average skills, semi-skilled foreign workersare commonly associated with the one constantly within the industry and have been residing in Malaysia for minimal period. Last but not least, workers without any skill in any branch of construction trades are called unskilled workers. They usually work within construction site for basic works such as transporting materials, housekeeping, and other general works [17]. Considered as newcomers, unskilled foreign workers are made up of foreigners who came to Malaysia without any basic learning and systematic skills in construction [16]. Normally, they learned by examples of everyday chores, given that proper continuous advanced training is scarce. 


\section{Worker's accommodation and facility in construction site}

Temporary accommodation provides fully equipped shelter to employees who are away from their homes, in a form of comfortable room, dining room, common living room, etc. Meanwhile facilities include communication facilities, recreational supports, medical service, efficient security, etc.[4]. Temporary accommodation and facility should be operated by facility contractor specialist who provides and maintains its standard of care and responsibility through appropriate facility manager. Every effort needs to be executed to reduce the side effects of temporary accommodation and facilities of the area and the surrounding people[4]. Hence, based on typical considerations for initial commencement of such respective move, there are several facets of characteristics need to be pondered, namely; type of workplace, work-related location, type of work to be carried out, number of employees in the workplace, party in charge of work and accommodation, working period(i.e. standby, shifts, etc.), and availability of disable/unfortunate worker [8].

\section{Malaysian standards of temporary construction site workers' amenities and accommodation - code of practice (MS 2593:2015)}

MS 2593: 2015 was spearheaded by SIRIM since 2014 and was published in December 2015 [4]. The objective is to provide official explanations of the needs for temporary facilities, which include construction workers' welfare, and safety and health of the employees which are deemed appropriate and organised. Furthermore, it also provides reference and guidance towards the provisions in providing reasonable temporary conveniences that are able to be implemented. In MS 2593: 2015, Malaysia is targeting for better accommodation and facilities to the workers at construction site due to various benefits, which through the end will pave direction for respective gazetted act. Within this document, thorough guidelines were presented, where it was divided by ten (10) sections with corresponding sub-sections. For instances; room (with arrangement of beds, wardrobes, lighting, and natural ventilation), sanitary facilities (with toilets, bathrooms, etc.), kitchen and dining place, water supply, toilet (including proper discharged of used water, sewage, and solid particles), drainage, electrical generation, medical facilities and first aid, social and recreational facilities, and signboards availability. Additionally, the guideline is also described in detail on the substantive needs that optimally should be provided in each convenience given.

\section{Standards/Guidelines from other countries}

There are several related standards from other countries namely Australia, Britain, and the United States of America (USA). Thus, this topic is presented to briefly explain about the particular standards. Standard practice code for Australian sets the practical guidelines in order to achieve the required level of safety at the workplace. Under their safety act (Safety Act, 2008), specific reference to minimum standards of facilities for people involved in construction work is provided [8]. The approved code is designed to be used along with the Work Safety Act and Regulations, but does not have similar legal force where a person or company cannot be prosecuted if they fail to abide to this practice code. The code should be followed unless there are alternative courses of action which able to achieve either similar or better implementation-wise of safety in the workplace. Apart, the code covers guidelines in providing facilities which are based on approved budget which then narrowed down into general provisions, exchanged rooms, dining places, toilet and sanitary, washing place, 
water supply, and personal closet. Additionally, according to the Australia's Office of Regulatory Services (ORS), relevant inspector can approve additional codes that are relevant to any improvement, or may release Prohibition Notice (PN) to indicate appropriate steps that should be taken to rectify the violation or non-compliance with current acts or the rules of safety [10].

On the other hand, a Guidance Note by the British Councils aimed at providing practical guidance to International Finance Corporation (IFC) (a member of the World Bank Group) and the European Bank for Reconstruction and Development (EBRD) specialists, consultants, and clients on the processes and standards that should be applied to the provision of workers' accommodation in relation to projects funded by them [18]. Running through the particular guideline, applying appropriate standards to the construction and operation of worker housing falls under the performance requirements on worker and also expected working conditions. The Guidance Note also provides examples of good practice approaches that businesses have successfully applied in their past operations. Additionally, a range of different types of workers' accommodation that may be required by various projects and at different stages within projects was documented, these include temporary exploration camps, construction camps, and permanent dormitories. Likewise, the guideline took an initiative to review various international, national, private sector and public sector standards, and other generally applicable guidance. Besides, the guideline promotes implementation and compliances with at least expected minimum benchmark [18].

Separately, a standard provided to Occupational Safety and Health Administration (OSHA) of United States of America aimed to assure safe and healthful working conditions for workers [33]. Apart from delivering guidance focused on workers' accommodation and welfare in construction setting, the said standard (1910.142) became a critical basis for setting up and enforcement of multiple betterment approaches such as training, outreach, education, and any related assistances. Published on 1988 by the United States Departments of Workers, the standard outlaid guidance on implementation of appropriate facilities or conditions which mostly fond towards safety and health of employees, regardless of occupying period in the forms of proper site drainage, shelter, water supply, toilet, laundry facility, handwashing and bathing conveniences, first aid amenities, refuse disposal, etc.

\section{Qualitative comparisons on several standards based on Malaysia's MS 2593:2015}

Comparison between different documents in term of their latent and manifest values often requires qualitative undertakings. Thus, due to answer prior research question, the authors attempted to impart both values; latent through variables' mapping processes of similar meanings among documents (regardless of sentence's or description's length), and manifest by variables' existence and frequency summary. Given the fact that manual qualitative comparison among the MS 2593:2015 and other standards or guidelines are prone to inconsistency, usage of available software (i.e. NVivo Ver.8) is considered useful. Steered by the works of several previous researchers, namely; Gibbs [19], Richards [20], Grbich [21],Wiltshier [22], Kariya et al. [23], and Ariffin et al. [24], the authors embarked on qualitative analysis based on the following diagram (Fig. 1) which is further described accordingly.

There are 17 variables in MS2593: 2015 which cover the entirety of construction workers' accommodation and facility's segments. These variables were transferred as nodes (using short abbreviations) in Nvivo as shown in Fig. 2. Next, coding exercises of essential words/texts from the MS2593: 2015 were conducted, originally imported into NVivo in MS Word's format, and coded under their respective nodes. Therefore, an appropriate amount 
of specific text(s) that has been coded to a specific node will reflect the final percentage of the node.

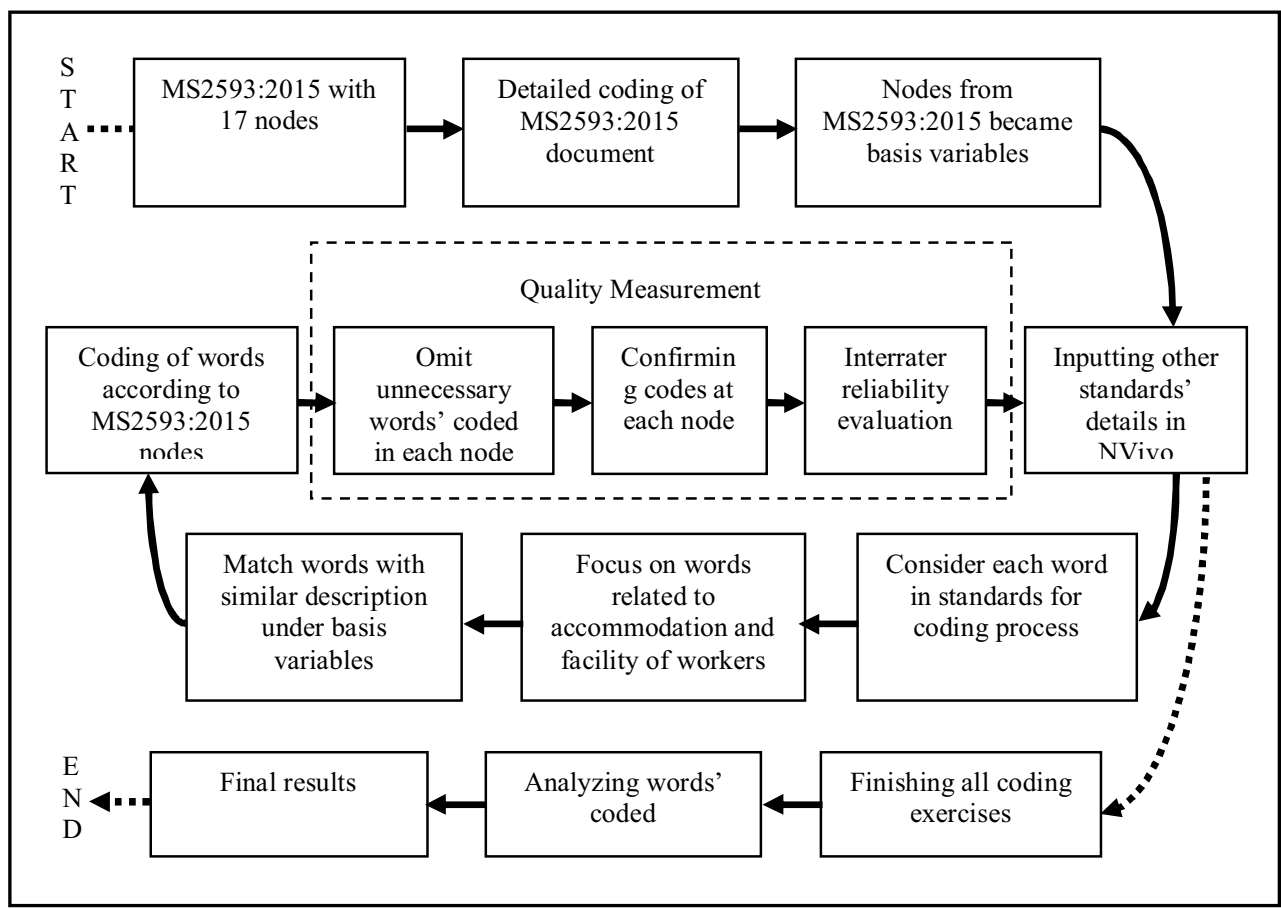

Fig. 1. Overall looping processes through NVivo

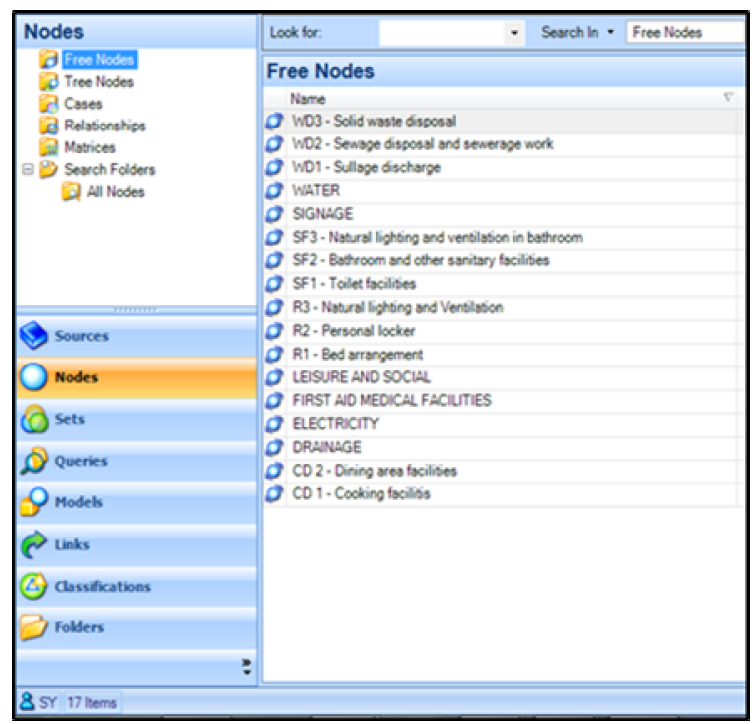

Fig. 2. Screenshot of nodes created in Nvivo based on MS2593: 2015.

Finally, nodes will be the basis of reference for consecutive coding exercises. Besides, guideline documents' obtainment generally relied on online sources, where completeness is 
of major consideration apart from their suitability. In this preliminary study, the authors were successful in gathering applicable guidelines issued by other countries, namely; the United States of America (1910.142), Britain (Guidance Note), and Australia(Safety Act, 2008). The following figure (Fig. 3) shows the inputted guidelines' folders in NVivo, along with their corresponding documents. Beforehand, importing other documents can be done either through MS Word's or PDF's format. As an internal source in NVivo (Fig. 3), commencement of documents' coding exercises of words is based on predetermined nodes. The process takes all relevant words/texts and was entered into their respective nodes without any editing work.

\begin{tabular}{|c|c|c|c|c|}
\hline Sources & \multicolumn{3}{|c|}{ Seurch in = Guideline } & Find Now Cles \\
\hline B 19 internals & \multicolumn{4}{|l|}{ Guideline } \\
\hline 2 Edernals & \multicolumn{2}{|l|}{ Name } & Modes & Reteriences \\
\hline 3 Memos & \multicolumn{2}{|l|}{ D) Australia } & 13 & 15 \\
\hline B $\mathbb{B}$ Search Folders & \multicolumn{2}{|l|}{ D Brissh Council } & 9 & 13 \\
\hline 2] All Sources & & 17 & 18 \\
\hline 2] All Sourtes Not Embedded & D United State & & 13 & 18 \\
\hline & \multicolumn{2}{|l|}{ Whashinton } & 12 & 14 \\
\hline & \multicolumn{4}{|l|}{ D sirim Guideline } \\
\hline $\begin{array}{l}\text { Sources } \\
\text { Nodes } \\
0 \text { sets } \\
0 \text { Queries } \\
9 \text { Models }\end{array}$ & \multirow[t]{3}{*}{ ROOM } & Bed arrengement & \multicolumn{2}{|c|}{$\begin{array}{l}\text { and hygienic conditions to rest and sleep. Bed } \\
\text { arrangement shall be as follows: } \\
\text { a) separated for each worker: } \\
\text { b) where double } \\
\text { - deck burks are used, there shall be } \\
\text { enough clear space between the lower and upper } \\
\text { bunk of } \\
\text { the bed. Minimum range from } 0.70 \mathrm{~m} \text { to } \\
1.10 \mathrm{~m} \text {; and } \\
\text { c) each worker is provided with a mattress } \\
\text { and pillow. }\end{array}$} \\
\hline C Links & & Personal locker & \multicolumn{2}{|c|}{$\begin{array}{l}\text { Personal locker of adequate size shall be provided } \\
\text { for storage of personal belongings }\end{array}$} \\
\hline $\begin{array}{l}\text { (4) Classifications } \\
\text { Foldens }\end{array}$ & & $\begin{array}{l}\text { Natural lilighthing } \\
\text { and ventilation }\end{array}$ & \multicolumn{2}{|c|}{$\begin{array}{l}\text { Every room shall be provided with: } \\
\text { a) windows or openings having an aggregate } \\
\text { area of not less than } 5 \% \text { of the floor area } \\
\text { of the room; or } \\
\text { h) merhaniral wentilatinn }\end{array}$} \\
\hline
\end{tabular}

Fig. 3. Guidelines' folder and an example of document's format in NVivo.

\subsection{Embedded quality measure}

In order to maintain concise and reliable coding exercises, all codes in every single node were scrutinised once more where unnecessary codes were removed (i.e. codes that do not contribute to overall meaning of node). Then, interrater reliability assessment is conducted, which is able to be seen as an indicator for trustworthiness of the coding processes and might as well contributes to its validity [25]. Additionally, the assessment of coding consistency towards either two or more coders is aimed at identifying the reliability for inner coding processes [26 - 28]. It is a crucial evaluation in order to verify reproducibility of coding through previously identified coding steps ( Fig. 1). Therefore, driven by the works of Lacobucci [29], Gwet [26], Graham et al. [27], Freelon [30], Hallgren [28], Roberts [31], the research embarked on the particular assessment by selecting a second coder (i.e. senior construction's lecturer). Initially, the judge's coder was briefed and closely recruited for the process towards one document, namely; the US standard (1910.142). The results (Table 1) were in a form of dichotomously coding presence between the two coders within all nodes (i.e. 1 for Yes and 0 for No).

From the analysed data, percentage agreement and Cohen's Kappa are selected as appropriate analysis for coding presence among two coders. As consensus estimates towards nominal data, percentage agreement between two coders is able to evaluate agreement of construct's interpretation [32,37,30]. On the other hand, the application of mathematical improvements for chance agreement between coders through Cohen's Kappa is considered more computationally robust [30, 32, 29, 26, 27]. The analysis was helped by 
a web-based software created by Freelon [30], and was compared to Graham's rule of thumb (Table 2)[27]. Finally, the results as in Table 3 show that percentage agreement of $88.2 \%$ is nearing high benchmark, while Cohen's Kappa of 0.679 is just slightly above the suggested minimum level. Although both results outlaid acceptable outcomes, lower Kappa's however might indicate certain shortcomings during recruitment processes towards the judge's coder. Nevertheless, it is deemed that coding exercises through NVivo are sufficiently reproducible without having to assess all documents $[25,32]$.

Table 1. Result for coding presence of two coders towards similar document of Washington standard.

\begin{tabular}{|l|c|c|}
\hline \multicolumn{1}{|c|}{ Basis Variables } & Judge's Coder & The Authors \\
\hline Cooking Area & Yes & Yes \\
\hline Dining Area & Yes & Yes \\
\hline Drainage & No & Yes \\
\hline Electricity & Yes & Yes \\
\hline First Aid Medical Facilities & No & No \\
\hline Leisure And Social & Yes & Yes \\
\hline Bed Arrangement & Yes & No \\
\hline Personal Locker & Yes & Yes \\
\hline Natural And Ventilation & Yes & Yes \\
\hline Toilet Facilities & Yes & Yes \\
\hline Bathroom /Sanitary Facilities & Yes & Yes \\
\hline Lighting And Ventilation & No & No \\
\hline Signage & Yes & Yes \\
\hline Water & Yes & No \\
\hline Sullage Discharge & Yes & Yes \\
\hline Sewage Disposal & Yes & Yes \\
\hline Solid Waste & Yes & \\
\hline
\end{tabular}

Table 2. Rule of thumb for interpreting interrater result [27]

\begin{tabular}{|l|c|c|}
\hline Interrater reliability & High & Minimum \\
\hline Percentage agreement & $90 \%$ & $75 \%$ \\
\hline Cohen's Kappa & .81 & .61 \\
\hline
\end{tabular}

Table 3. Interrater reliability assessments' results

\begin{tabular}{|c|c|c|c|c|c|c|}
\hline $\begin{array}{c}\text { Interrater } \\
\text { reliability }\end{array}$ & $\begin{array}{c}\text { Agreement } \\
(\%)\end{array}$ & $\begin{array}{c}\text { Cohen's } \\
\text { Kappa }\end{array}$ & $\begin{array}{c}\mathbf{N} \\
\text { Agreement }\end{array}$ & $\begin{array}{c}\mathbf{N} \\
\text { Disagreement }\end{array}$ & $\begin{array}{c}\mathbf{N} \\
\text { Cases }\end{array}$ & N Decisions \\
\hline $\begin{array}{l}\text { Between coders } \\
\text { (i.e. Judge \& } \\
\text { Authors) }\end{array}$ & $88.2 \%$ & 0.679 & 15 & 2 & 17 & 34 \\
\hline
\end{tabular}

\subsection{Analysis and extractions}

While the latent part was already being partly embedded in the previous section, the final step is the process of analysis and extraction to achieve study's objective. Analysis was divided into several parts including the frequency and percentage of words coded, and their intensities. Those parts are considered important due to the fact that since the integral meaning of numerous codes were dedicated to its particular nodes, subjective issue on similarities of words'/texts' usage is not a concern in this preliminary study, but their comprehensiveness in visualising each node through writings is of major objective. Coupled with detail comparisons between currently applied international standards, therefore, the authors were positive towards exploring the applicability of MS2593: 2015. 
To begin with, existence of codes signifies certain consideration that had been given for a particular node, while frequency dictates their comprehensiveness among other documents. As shown in Table 4, it is no surprise that MS2593: 2015 dominate the dichotomous column of codes' existence since they become basis reference of nodes. Following closely are the Australian 2003 and the United States 1910.142 where both have 13 positive nodes. The least can be observed from the British Council 2009 with only 9 nodes. On the other hand, MS2593: 2015 topped the list of frequency of words coded for a single document, with only a difference of ten (10) codes separate Malaysia standard (1043 codes) with the US's (1034 codes). Finally, quite significant gaps persist for the rest of standards in term of their codes' frequency, namely; the Australian 2003 (663 codes) and the British Council 2009 (404 codes). Furthermore, Table 4 also highlighted (i.e. in deeper colour) some variables which has recorded higher frequency of codes for certain variables in few documents. Indirectly it is the evidence that supports particular documents' concentration on workers accommodation and facility's variable. Apart, lighter colour was applied for less concentrated variables.

Table 4. Existence of code(s) and frequency of words coded in every nodes

\begin{tabular}{|c|c|c|c|c|c|c|c|c|}
\hline \multirow{2}{*}{$\begin{array}{l}\text { Basis Variables } \\
\text { Cooking Area }\end{array}$} & \multicolumn{2}{|c|}{$\begin{array}{l}\text { Australia, } \\
2003[8]\end{array}$} & \multicolumn{2}{|c|}{$\begin{array}{c}\text { British } \\
\text { Council, } \\
2009[18]\end{array}$} & \multicolumn{2}{|c|}{$\begin{array}{c}\text { Malaysia } \\
\text { MS2593: } 2015 \\
{[4]}\end{array}$} & \multicolumn{2}{|c|}{$\begin{array}{l}\text { United States, } \\
1910.142[33]\end{array}$} \\
\hline & Yes & 32 & No & 0 & Yes & 60 & Yes & 99 \\
\hline Dining Area & Yes & 12 & No & 0 & Yes & 92 & Yes & 209 \\
\hline Drainage & Yes & 42 & No & 0 & Yes & 42 & Yes & 42 \\
\hline Electricity & Yes & 90 & No & 0 & Yes & 29 & Yes & 90 \\
\hline First Aid Medical Facilities & Yes & 50 & No & 0 & Yes & 17 & Yes & 50 \\
\hline Leisure and Social & No & 0 & No & 0 & Yes & 80 & No & 0 \\
\hline Bed Arrangement & Yes & 63 & Yes & 68 & Yes & 72 & Yes & 128 \\
\hline Personal Locker & No & 0 & Yes & 22 & Yes & 13 & No & 0 \\
\hline Natural and Ventilation & Yes & 69 & Yes & 35 & Yes & 28 & Yes & 64 \\
\hline Toilet Facilities & Yes & 38 & Yes & 68 & Yes & 262 & Yes & 31 \\
\hline Bathroom /Sanitary Facilities & Yes & 169 & Yes & 22 & Yes & 79 & Yes & 14 \\
\hline Lighting and Ventilation & No & 0 & Yes & 20 & Yes & 49 & Yes & 78 \\
\hline Signage & No & 0 & No & 0 & Yes & 77 & No & 0 \\
\hline Water & Yes & 35 & Yes & 90 & Yes & 62 & Yes & 137 \\
\hline Sullage Discharge & Yes & 21 & No & 0 & Yes & 25 & No & 0 \\
\hline Sewage Disposal & Yes & 21 & Yes & 16 & Yes & 28 & Yes & 19 \\
\hline Solid Waste & Yes & 21 & Yes & 63 & Yes & 28 & Yes & 73 \\
\hline $\begin{array}{l}\text { Frequencyof 'Yes" from } 17 \\
\text { nodes }\end{array}$ & 13 & & 9 & & 17 & & 13 & \\
\hline Frequency of words coded & & 663 & & 404 & & 1043 & & 1034 \\
\hline
\end{tabular}

Next, by variables, intensities of codes were tabulated according to its percentages in horizontal view. The move was intentionally done in order for the authors to further identify emphasis of each standard on observed variables. Based on Table 5, Malaysia's MS2593: 2015, and the US1910.142 was recorded similar achievement for highest percentage of concerning nodes but with dissimilar themes. Specifically; MS2593: 2015: drainage, leisure and social, toilet facility, signage, sullage discharge, and sewage disposal; and the US 1910.142: dining area, drainage, bed arrangement, lighting and ventilation, water, and solid waste facility. Here, all standards showed a number of analogous percentages, precisely for the provision of drainage at workers accommodation, except for the British Council 2009. Nevertheless, for MS2593: 2015, interestingly, there are two (2) variables that achieved full percentage since they are not currently being offered by other standards, namely; leisure and social, and signage. Apart, the remaining standards (i.e. the 
British Council 2009) posted lower achievement for highest percentage accurately for the provision of personal locker.

Table 5. Percentage of codes in every variable (i.e. nodes)

\begin{tabular}{|c|c|c|c|c|c|}
\hline Basis Variables & $\begin{array}{c}\text { Australia, } \\
2003[8]\end{array}$ & $\begin{array}{c}\text { British } \\
\text { Council, } \\
2009 \text { [18] }\end{array}$ & $\begin{array}{l}\text { Malaysia } \\
\text { MS2593: } \\
\text { 2015 [4] }\end{array}$ & $\begin{array}{c}\text { United } \\
\text { States, } \\
1910.142[33] \\
\end{array}$ & $\begin{array}{c}\text { Total } \\
\text { horizontal } \\
\text { percentage }\end{array}$ \\
\hline Cooking Area & $9.5 \%$ & - & $17.8 \%$ & $29.38 \%$ & \multirow{18}{*}{$100 \%$} \\
\hline Dining Area & $2.61 \%$ & - & $20.04 \%$ & $45.53 \%$ & \\
\hline Drainage & $33.33 \%$ & - & $33.33 \%$ & $33.33 \%$ & \\
\hline Electricity & $29.9 \%$ & - & $9.63 \%$ & $29.9 \%$ & \\
\hline $\begin{array}{l}\text { First Aid Medical } \\
\text { Facilities }\end{array}$ & $29.76 \%$ & - & $10.12 \%$ & $29.76 \%$ & \\
\hline Leisure and Social & - & - & $100 \%$ & - & \\
\hline Bed Arrangement & $13.73 \%$ & $14.81 \%$ & $15.69 \%$ & $27.89 \%$ & \\
\hline Personal Locker & - & $62.86 \%$ & $37.14 \%$ & - & \\
\hline $\begin{array}{l}\text { Natural and } \\
\text { Ventilation }\end{array}$ & $26.54 \%$ & $13.46 \%$ & $10.77 \%$ & $24.62 \%$ & \\
\hline Toilet Facilities & $8.19 \%$ & $14.66 \%$ & $56.47 \%$ & $6.68 \%$ & \\
\hline $\begin{array}{l}\text { Bathroom /Sanitary } \\
\text { Facilities }\end{array}$ & $42.36 \%$ & $5.51 \%$ & $19.8 \%$ & $3.51 \%$ & \\
\hline $\begin{array}{l}\text { Lighting and } \\
\text { Ventilation }\end{array}$ & - & $9.3 \%$ & $22.79 \%$ & $36.28 \%$ & \\
\hline Signage & - & - & $100 \%$ & - & \\
\hline Water & $7.59 \%$ & $19.52 \%$ & $13.45 \%$ & $29.72 \%$ & \\
\hline Sullage Discharge & $45.65 \%$ & - & $54.35 \%$ & - & \\
\hline Sewage Disposal & $20.19 \%$ & $15.38 \%$ & $26.92 \%$ & $18.27 \%$ & \\
\hline Solid Waste & $8.14 \%$ & $24.42 \%$ & $10.85 \%$ & $28.29 \%$ & \\
\hline $\begin{array}{l}\text { Achievement for } \\
\text { highest percentage } \\
\text { (darker boxes) }\end{array}$ & 3 & 1 & 6 & 6 & \\
\hline
\end{tabular}

\section{Conclusion and way forward}

The Malaysia standards (MS2593: 2015) which have 17 noticeable variables on workers accommodation and facility were tested and corroborated towards several other counterpart countries' standards. In seeking its corroborative levelwithout undergoing real life testing, qualitative approach through document analysis was conducted. A thorough steps as in Fig. 1 was implemented to maintain reliable outcomes, backed by positive results of interrater reliability assessments (i.e. percentage agreement and Cohen's Kappa). In a nutshell (i.e. based on Table 4 and Table 5), the authors posited that the MS2593:2015 is on par with other distinguished standards especially from the US 1910.142. Although the MS2593:2015 is seen as focusing on certain variables (i.e. drainage, toilet facility, sullage discharge, and sewage disposal), an introduction of new variables of leisure and social, and signage is applauded to give better values towards construction workers. Indirectly, those initiatives might support government efforts in recruiting more local talents to be involved in the particular industry. Nevertheless, given the fact that MS2593:2015 is comparatively a new guideline, implementation-wise needs to consider collective actions especially towards the enforcement (e.g. the policymaker) and application body (e.g. the contractor). Thus, the authors concluded, findings from the paper has attested the corroborative level of Malaysia's MS2593:2015 which deemed beneficial for the author's subsequent undertakings, and to a certain extent providing an insight towards related stakeholders. However, further research on feedbacks from industries stakeholders, and ground 
observation of current practices and offerings in term of workers accommodation and facility are inevitable before any subsequent initiatives are introduced (e.g. gazetting act).

The authors would like to thank the Universiti Tun Hussein Onn Malaysia for their assistances throughout the introductory phase of research and sponsoring the inaugural paper.

\section{References}

[1] Construction Industry Development Board (CIDB) Malaysia, Construction Industry Transformation Programme (CITP) 2016-2020, No. 1. Malaysia: Construction IndustryDevelopment Board (CIDB) Malaysia, (2015)

[2] G. Ofori, Nature of the construction industry, its needs and its development, A Review of Four Decades of Research, 20(2), 115-135, (2015)

[3] Pook Ah Lek, The dilemma of having foreign workers in Malaysia, Sin Chew Daily, Malaysia, (Sept. 2016)

[4] Department of Malaysia Standard, Temporary construction site workers' amenities and accommodation - Code of practice MS 2593:2015. Malaysia: Department of Standards Malaysia, (2015)

[5] Lembaga Penyelidikan Undang-undang, Akta Standard-Standard Minimum Perumahan dan Kemudahan Pekerja, 1990 (AKTA 446), Malaysia, (1990)

[6] I. Rozlin and M.H Ismail, Kuarters tangani isu pekerja asing, Sinar Online, ( July 15 2015)

[7] Jabatan Kerja Raya Malaysia, Standard Specifications for Building Works 2014. Malaysia: Jabatan Kerja Raya Malaysia, (2014)

[8] Government of South Australia, Guidelines for Workplace Amenities and Accommodation. Australia: WorkCover Corporation, (2003)

[9] B.Y. Jeong, S. Lee and J. D. Lee, Workplace Accidents and Work-related Illnesses of Household Waste Collectors, Saf. Health Work, (2015)

[10] Department of Justice and Community Safety, Australian Code Of Practice Rail Safety Investigation, Australia: Department of Justice \& Community Safety, 2, (2010)

[11]Y. Md Junus, Kajian hak pekerja di tapak bina mengikut peruntukan undang-undang, Master Thesis , Universiti Teknologi Malaysia, (2002)

[12]M. Government, Employment Act 1955, April, 1-120, (2012)

[13]A. Hamid and B. Singh, Problems faced by contractors in managing foreign workers on construction sites, $2^{\text {nd }}$ Int. Conference on Construction and Project Management, 15,131-135, (2011)

[14]Jabatan Imigresen Malaysia, Pekerja Asing Separa Mahir dan Kurang Mahir, Jabatan Imigresen News, (2004)

[15]N. Jaffar, A.H. Abdul Tharim and M. N. Shuib, Factors of conflict in construction industry: A literature review, Procedia Engineering, 20, 193-202, (2011)

[16] O. S. Wei, Kesan pengurangan buruh asing dalam industri pembinaan. Kajian kes di Johor Bahru, Master Thesis , Universiti Teknologi Malaysia, Skudai, Malaysia, (2002)

[17] A.M. Ismail, Penggunaan buruh asing dalam industri pembinaan di Johor, (2003)

[18] International Finance Corporation and European Bank for Reconstruction and European Bank for Reconstruction and Development, Workers' accommodation: processes and standards A guidance note by IFC and the EBRD, European Bank for Reconstruction and Development and International Finance Corporation, London, (2009)

[19]G. Gibbs, Qualitative data analysis: Explorations with NVivo, Philadelphia, USA: Open University Press, (2002) 
[20]L. Richards, Handling qualitative data: A practical guide, London: Sage Publications, London, (2005)

[21]C. Grbich, Qualitative data analysis: An introduction, London: SAGE Publication Ltd, London, (2007)

[22]F. Wiltshier, Researching with NVivo 8, Forum: Qualitative Social Research, 12(1), 112., (2011)

[23]N. Kariyaa, Z. Yaakobb, M.N.M Sairia, H. Mohammadc, S.K Yaman and R. Yunus, Investigation of generic house components and their practical assessment during defect liability period ( DLP ) in Malaysia, Int. J. of Engineering, 29(10), (2016)

[24] S.Ariffin, Z. Yaakobb, S. Sulaiman, H. Mohammad, S.K Yaman, Factors of economies of scale for abstract, Int. Congress on Technology, Engineering and Science Conf., Kuala Lumpur, Malaysia, (2016)

[25]P.B. Jackson, Qualitative data analysis with Nvivo, Second Edi. London: British Library, (2013)

[26]K.L. Gwet, Computing inter-rater reliability and its variance, British J. of Mathematical and Statistical Psychology,61,29-48, (2008)

[27]M. Graham, A. Milanowski and J. Miller, Measuring and Promoting Inter-Rater Agreement of Teacher and Principal Performance Ratings, (February,2012)

[28]K. Hallgren, Computing inter-rater reliability for observational Data: An overview and tutorial, Tutorials in Quantitative Methods for Psychology, 8(1), 23-34, (2012)

[29]D. Iacobucci, Factor analysis, J. Consum. Psychol. Spec. Issue Methodol. Stat. Concerns Exerimental. Behaviour Researcher., 10(1\&2), 75-82, (2001)

[30]D.G. Freelon, ReCal: Intercoder reliability calculation as a web service, Int. J. Internet Sci., 5(1), 20-33, (2010)

[31]R.E. Stake, Qualitative research: studying how things work, New York: The Guilford Press, London, (2010)

[32] S.E. Stemler, A comparison of consensus, consistency, and measurement approaches to estimating interrater reliability, Pract. Assess. Res. Eval., 9(4), 1-19, (2004)

[33] United States Department of Labor, US OSHA (2016), General environmental control: temporary labor camps, Retrieved on 2016 https://www.osha.gov/pls/oshaweb/owadisp.show_document?p_table=STANDARDS \&p_id=9791 